\title{
ISOISÄN MEIKKIPUSSI
}

Tuijotan ryhmäkuvaa, jossa parikymppinen isänisäni istuu ulkona kuuden nuoren aikuisen ja yhdeksän lapsen kanssa. 1930-luvun lopun kesäaurinko paistaa silmiin, hän siristää niitä, mutta katsoo kameraan hymyillen. Vieressä istuva nuori nainen on heittänyt kätensä isoisän kaulaan ja isoisä on ottanut hänen toisesta kädestään vauhdikkaan tanssiotteen. Osalla kuvan aikuisista on erikoisen herraskaiset vaatteet, mikä viittaa näytelmäporukkaan. Isoisällänikin on tumma puvun takki ja valkoinen kauluspaita, kaulassa suuri rusetti. Hänen takanaan kohoaa kivijalka ja lautaseinä.

Ollaan eteläisessä Satakunnassa, NaarjoenTurajärven työväentalolla, joka pystytettiin talkoilla kahden kylän rajalle 1910-luvun alussa. Kuvassa eletään talon kulta-aikaa, jolloin suomalaisten enemmistö asui maaseudulla ja Naarjoen kaltaisissa pienissä kylissäkin oli paljon nuoria. 1920-luvun lopulla teini-ikäisiä oli Suomessa enemmän kuin koskaan ennen, ja 1930-luvulle tultaessa he muodostivat suuren

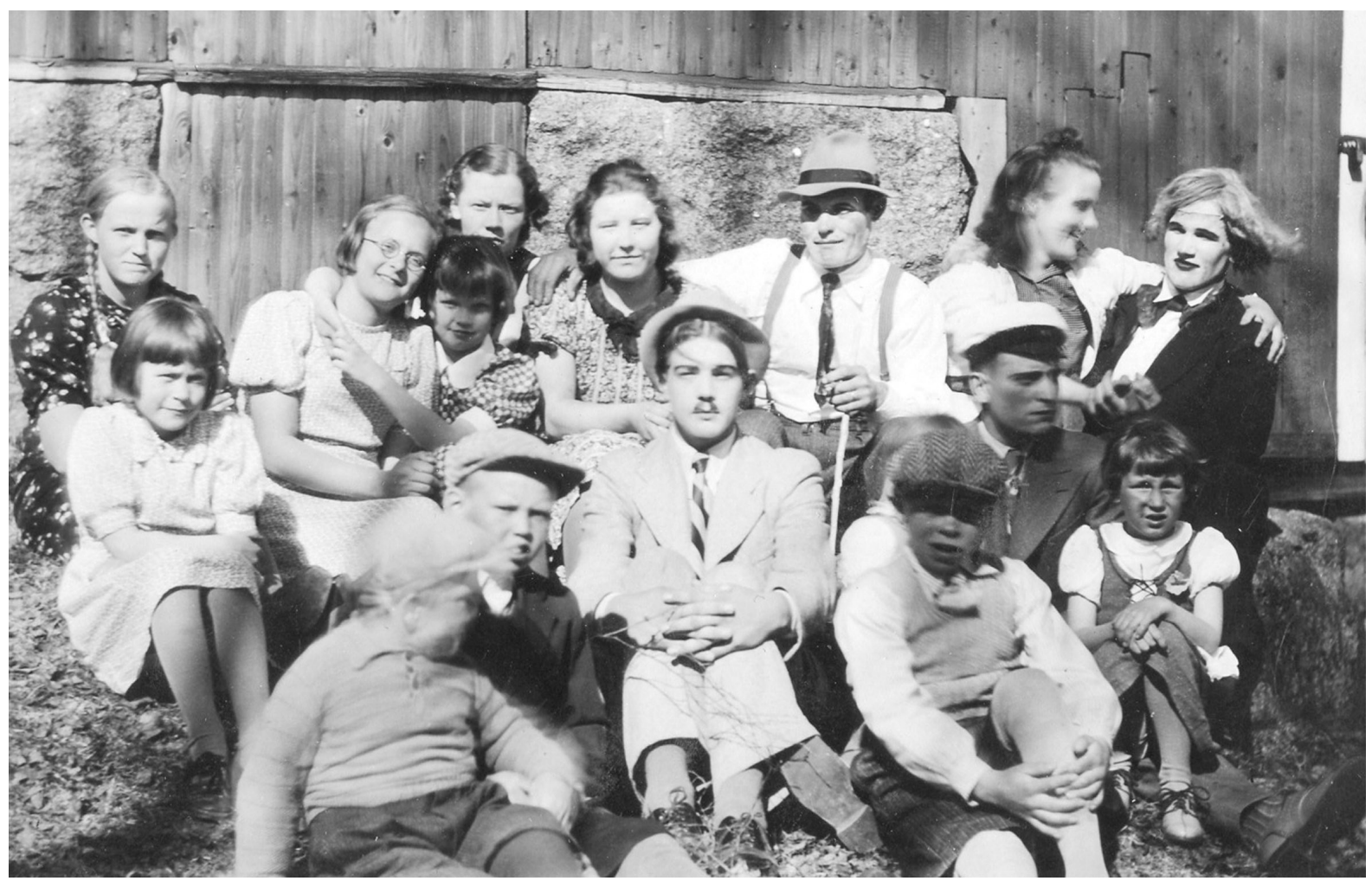

KUVA: Isoisäni (takarivissä oikealla) Naarjoen-Turajärven työväentalolla 1930-luvun lopulla. Kuva Oiva ja Liisi Männistön kotialbumista.
Pervopeili Artikkelit

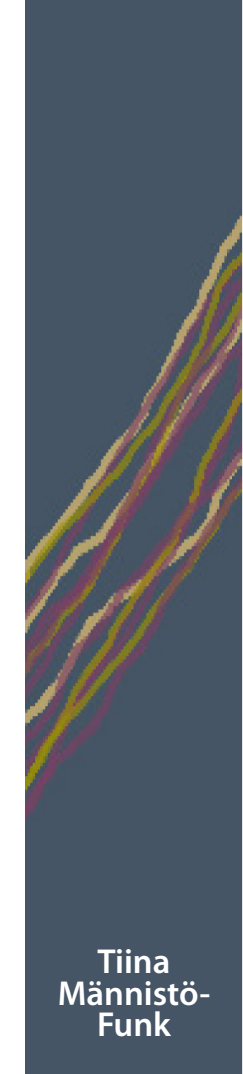


nuorten aikuisten joukon (Haapala 2003, 67-70). Isoisäni oli aktiivinen työväenyhdistyksessä, kuten isänsäkin. Molemmat myös viljelivät vuorollaan samaa pientilaa, itsenäiseksi ostettua Männistön torppaa.

Oma isäni sanoo, että tämä kuva on ollut isovanhempieni albumeissa, mutta en muista koskaan ennen nähneeni sitä. ${ }^{1}$ Nyt en saa silmiäni irti kuvasta, isoisästäni siinä. Hänellä on päässään puolipitkä vaalea peruukki. Hänellä on paksulti silmämeikkiä. Hänellä on varsin dramaattisesti maalatut huulet. Oletettavasti punaiset, vaikkei sitä mustavalkokuvasta pystykään varmuudella sanomaan.

Papaksi minä häntä kutsuin. Minun tullessani kouluikään hän sairastui ja joutui vuosikausiksi kirkonkylälle, Euran terveyskeskuksen vuodeosastolle. Ajalta ennen vuodeosastoa muistan hänestä vain välähdyksiä: suuren karhumaisen olemuksen, möreän äänen, keinutuolin tuvassa ja putkiradion merisään. Pääsin serkkuni kanssa traktorin kyytiin, kun pappa haki metsästä riukuja. Autoa hänellä ei koskaan ollutkaan, hän kulki joka paikkaan traktorilla.

Mielikuvieni isoisä on oman ikäluokkansa suomalaisen miehisyyden ruumiillistuma, talvi- ja jatkosodan käynyt, talonsa rakentanut ja leipänsä viljellyt, omillaan toimeentuleva, kovaääninen ja hieman pelottavakin, tuhattaitoinen tilan töissä mutta eteenpassattava ruokapöydässä, seitsemän lapsen ankara isä, sosiaalinen erityisesti muiden miesten seurassa. Mutta tässä kuvassa hän nyt on toisenlaisena, nuorena, hupsuna ja täydessä tällingissä. Mistä tässä oikein on kyse?

1 Isälleni kiitos siitä, että sain tutustua tähän kuvaan ja moniin sukua koskeviin asioihin kahdessa hänen kirjoittamassaan kirjassa: Männistö 2014 \& Männistö 2017.

\section{Isoisotädin tyttöystävän kravatti Berliinin klubeilla}

Kultahile lentää ilmaan, samppanjaa kaadetaan, muodikkaat lyhyet mekot ja pitkät kaulanauhat heilahtelevat kuumeisen tanssin tahdissa. Zu Asche, zu Staub! Babylon Berlin! Katsomme sarjaa puolisoni kanssa kotisohvalla. Berliinin murre on ihanaa, Charlotte Ritter on ihana, 1920-luvun lopun kaupunkikulttuurin vyöryttäminen on ihanaa. Tosin kritisoin jatkuvasti, että katuotoksissa näkyy liian vähän polkupyörïa. ${ }^{2}$ Samaa, tarkoituksellistakin historiallista epätarkkuutta on monissa kohdissa. Kuten kulttuurintutkija Jaakko Suominen (2018) kirjoittaa, sarja sijoittuu historiallisen 1920-luvun sijaan "1920-luvun yhteisesti kuviteltuun todellisuuteen, imaginaariseen paheelliseen 1920-lukuun." Tämä ei ole ajankuvaa, vaan ajankuvitelmaa, sellainen näkymä 1920-lukuun, jossa voimme peilata itseämme.

Nykykulttuurille nyökäten sarjan yökerhoissa esiintyvät myös dragkingit ja -queenit. Svetlana Sorokina esittää sarjan nimikappaletta mieheksi pukeutuneena ylellisen ja paheellisen klubin dramaattisena vetonaulana, kun taas Holländer-baarissa tavataan transvestiitteja tai dragiin pukeutuneita miehiä. Yritän nähdä, onko Holländerissa lesboiksi tulkittavia naishahmoja, mutta kamera keskittyy miehiin. "Clairen pitäisi esiintyä tässä”, sanon puolisolle. Seuraavana päivänä etsin internetistä ateljeevalokuvan, joka on otettu Saksassa vuonna 1918, ja tuijotan sitä lähes yhtä intensiivisesti kuin isoisäni kuvaa. Laulajana sittemmin mainetta hankkinut Claire Waldoff istuu kuvan etualalla, tunnusomaisessa polkkatukkakampauksessaan, yllään vaalea kauluspaita ja tumma kravatti. Häneen nojaa koko vartalollaan puolisoni isoisotäti, Olga (Olly) von Roeder. Olly hymyilee onnellisesti, harsokkaaseen hattuun ja helmikorvakoruihin sonnustautuneena. ${ }^{3}$ Waldoff ja Roeder ovat juuri tavanneet teatteriproduktiossa ja rakastuneet.

2 Ks. esim. Männistö-Funk 2019, 13; Männistö-Funk 2012, 52.

3 Kuvan voi löytää esimerkiksi tästä osoitteesta: http://andrejkoymasky.com/ liv/fam/biov2/vonroed01.html

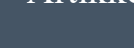


Tästä eteenpäin he elivät pariskuntana loppuelämänsä. 1920-luvulla he olivat Berliinin lesbopiirien keskiössä. (Koreen 2014.)

Waldoffista tuli lyhyen teatteriuran jälkeen kabareelaulaja, jonka levytykset saavuttivat myyntiennätyksiä. Suosionsa huipulla hän oli 1920-luvulla ja esiintyi Berliinin suurimmissa varietee-teattereissa, usein miesten pukuun pukeutuneena. Nimenomaan kabaree oli 1920-luvun Saksassa areena, jolla erilaisia sukupuolen ilmaisutapoja voitiin haastaa yli kaksijakoisen dikotomian. Ristiinpukeutuminen oli tämän haastamisen näkyvimpiä keinoja, mutta lisäksi itse laulut ja niiden esitystavat antoivat tilaa sukupuolen moninaisuudelle ja toisenlaisuudelle, nykytulkinnan mukaan queerille. (Mungen 2006.) Waldoff laulaa vuonna 1928 levyttämässään kappaleessa suloisesta Hanneloresta, joka käyttää smokkia ja monokkelia, jolla on sekä sulhanen että morsian ja josta ei voi tietää, onko hän nainen vai mies. Vuonna 1926 vielä tuntematon Marlene Dietrich esiintyi Waldoffin kanssa. He nauttivat yhteisessä seurueessa yöelämästä esimerkiksi Eldoradossa, eräässä Berliinin muodikkaimmista yökerhoista. Paikan vetonaulana olivat esiintyvät transvestiitit, joiden kanssa vieraat saivat myös tanssia. (Raber 2003, 50-52.) Melko ilmeinen esikuva Babylon Berlinin Holländer-klubille siis. Neljä vuotta myöhemmin Dietrich oli jo ampaissut maailmanmaineeseen, lauloi frakissa sekä silinterihatussa ja suuteli naista Morocco-elokuvan kohtauksessa, josta tulisi yksi elokuvahistorian kuuluisimpia esimerkkejä ristiinpukeutumisesta.

Mutta mitä tekemistä tällä kaikella on sen ihmisen kanssa, joka vuosikymmen myöhemmin istuu työväentalon seinustalla Suomessa ja josta paljon myöhemmin tulee minun isoisäni? Berliini ja Naarjoki tuntuvat monella tapaa toistensa vastakohdilta. Minua alkaa huimata, kun mietin, mitä merkitsee identiteettien ja mahdollisuuksien kannalta se, että meistä, samalla sohvalla sarjoja katselevista, yhden suku on tanssinut Euroopan maineikkaimmilla klubeilla, samaan aikaan kun toisen suku on hoitanut lehmiä satakuntalaisessa pihanavetassa. Silti näen jonkinlaisen yhdistävän seitin, vaikkakin ohuen ja vaikeasti hahmotettavan. Jokin oli mahdollista 1920-1930-luvun Euroopassa, siellä ja täällä, vaikka väläyksittäin. Kun kabareetähti astui Marlene Dietrichin kanssa transvestiittiklubin paratiisilintujen joukkoon. Ja kun yksi ihan tavallinen pienviljelijän poika punasi huulensa ja asetti päähänsä peruukin työväentalolla. Yhdistäviä tekijöitä olivat ainakin näyttämöt ja tanssi.

\section{Parkkiintunu nahka, kyl se sen kesti}

Tanssittiin sitä Naarjoellakin, vaikkei kultasateessa ja höyhenpuuhkissa. Työväentalolla järjestettiin ahkerasti iltamia, joiden olennainen osa tanssi oli. Runsaan maalaisnuorison aikaan, 1920-30-luvuilla, seurataloilla kautta Suomen oli tungosta. Mielin määrin ei silti saanut huvitella. Tanssien järjestämistä verotettiin, ja verosta saattoi vapautua vain sitoutumalla tiukkoihin sääntöihin: ohjelmallisten iltamien päätteeksi sai olla korkeintaan tunti tanssia. (Pesola 1996, 105-107, 122-125.) Muun muassa tästä kertoo myös isoisäni kansatieteellisessä haastattelussa: Tampereen yliopiston kansatieteen professori Erkki Ala-Könni kierteli mopollaan maalaiskylissä nauhoittamassa kansanmusiikkia ja keräämässä muistitietoa 1940-luvulta lähtien. Alkuvuodesta 1979 hän saapui Männistön torppaan ja haastatteli isoisääni tämän jo kuolleen isän valokuvaustoiminnasta ja haitarinsoitosta. Saman vuoden kesäkuussa saapui paikalle Ala-Könnin tutkimusryhmässä kesätöissä ollut Helmi Järviluoma ja haastatteli isoisääni perusteellisesti työväenkulttuuriin liittyneistä asioista. Ja nyt minulla on haastattelu tässä näin, CD-levylle tallennettuna. Työnnän sen kotona soittimeen ja kuuntelen, mitä isoisäni kertoo iltamista ja tansseista:

"Kyl niit tansseja pidettiin, mut pidettiin myös ohjelmallissii iltamii. Et siel se oli sitte se kolmen tunnin ohjelma. Ja tunti tanssia. Mut sitä tupatti sit, ohjelma ei tahtonu ain niin paljon olla, koetettiin röpätä sit. Poliisit valvo sitä sit, ettei saanu tanssia enempää ku tunnin. Et 
jos tanssi alotetti ennen kahtakymmentkolmee niin sitte piti iltamat lopettaa aikaisemmin, mut ei se nyt ain käyny ja ei poliisitkaan mittä ain ollu paikal, ni sillo sit mittä hättä ollu. Sillo tanssitti sit vähä pidempään. Sotie jälke sitte se menikin siihe, et oli puolentoist tunnin tanssi."

Naarjoella, kuten kylissä ympäri maata, koettiin nyt ainutlaatuinen harrastelijaesiintymisten kausi. Verotussääntöjen takia iltamiin piti saada tarpeeksi ohjelmaa ennen tanssia. Niinpä tuvissa ja seurataloilla tankattiin ulkomuistiin näytelmän sanoja, harjoiteltiin mandoliinin säestyksellä poliittisia lauluja ja suunniteltiin voimisteluesityksiä. Naarjoen-Turajärven työväenyhdistyksen nuoriso-osastolla oli vaikuttava valikoima ohjelmaa kartuttavia ryhmiä: lauluja esittävät kisälli- ja kisällitärryhmät, voimisteluryhmät, joukkolausuntaryhmät sekä näytelmäryhmä. Mutta päällekkäisyyttäkin oli, kuten isoisäni muistelee:

”Jos oli esimerkiksi jotai taitovoimistelui tai semmossi, ni nämä samat miehet, ne suoritti, ne lauloi, ne voimisteli, ne oli lausumassa ja niist oli osa näytelmässäki viel mukan sit. Kyl siin semmone melko tiivis tuntuma oli ne illat. Ja välitöiksee sit vielä juonteli sitte, kuulutteli tätä ohjelmaa."5

Hänen puheessaan kuuluu erityinen painokkuus aina, kun näytelmistä tulee puhe. Vaikka hän oli mukana myös lauluryhmässä, olivat näytelmät selvästi hänelle erityisasemassa. Niiden kautta hän tulikin alkujaan mukaan yhdistyksen toimintaan viisitoistavuotiaana, vuonna 1934. Oli viikko kokoillan näytelmän esittämiseen, kun eräs pääosan esittäjä joutui poliisin pidättämäksi, ”vesikoppiin”, kuten isoisäni Järviluomalle toteaa. Ja niin hänet itsensä "temmattiin" mukaan: "Lyötii luntta mun kouraa sitte

4 Oiva Männistön haastattelu, Tampereen yliopiston kansanperinteen arkisto, äänitekokoelmat, Y 08381/1979-06-10.

5 Ibid. vaan. Ja siitä se lähti sitte.” Seuraavat viisi vuotta olivat hänelle vilkasta näytelmäaikaa, mutta sotien jälkeen hän toteaa ohjelmapuolen hiipuneen. Hänellä olisi ollut vielä intoa, mutta esiintyjiä ei ollut tarpeeksi. "Tanssi oli sit vienyt sen nuoren väen.”7 Ja niinhän siinä oli käynyt. 1950-luvulle mennessä kaupalliset tanssilavat ja suuret, ammattimaisesti järjestetyt tanssit olivat vieneet pohjan kylien pieniltä omaehtoisilta tansseilta (Nurmela 2005, 62-64).

Haastattelunauhoituksessa nuori Järviluoma kysyy kisällilaulujen laulajista ja säestäjistä. Toivon, että voisin kurkata hänen selkänsä takaa ja ujuttaa mukaan kysymyksen näytelmistä. Kysyä, mikä juttu se oli, kun sinulla oli huulipunaa, pappa, ja mitä näytelmiä te esititte. Mutta haastattelun aikaan olen vasta puolivuotias enkä ole paikalla. Ja vaikka olisinkin, tarvitaan vielä useampi vuosikymmen ja melkoisen pitkät yliopisto-opinnot, ennen kuin olen se ihminen, joka kysymyksen kysyisi. Nyt ne vuosikymmenet kuitenkin ovat kuluneet ja on myös tapahtunut niin, että Helmi Järviluomasta on tullut Facebook-kaverini. Kyseessä on juuri sellainen historiallisesti tyypillinen kohtalon oikku, joka käy pienviljelijän lapsenlapselle. Isoisäni viljeli maata, minä uusmaterialistista teoriaa. Laitan Järviluomalle viestin. Hän kertoo osallistuneensa kolmeen pitkään kenttäretkeen Ala-Könnin ryhmissä ja keränneensä erityisesti yhdistystoimintaan liittyvää perinnettä, Eurassa nimenomaan työväenperinnettä, joka oli siellä vahvaa. Tunnen jälleen lievää huimausta, kun ajattelen prosessia, jonka osana olen nyt tässä tarkastelemassa isoisän̈ni, ei pelkästään osana historiaa, vaan myös historian tuottamisen historiaa, ja lisäksi itseäni tämän historian tuottamisen historian subjektina ja objektina, sen tuottamisessa syntyvänä kokonaisuutena.

Mutta nyt haastattelussa päästään asiaan, vaatteisiin ja meikkeihin! Isoisäni kertoo, miten puvustoa haalittiin, mistä saatiin, ja koetettiin soveltaa

$$
\begin{array}{ll}
6 & \text { Ibid. } \\
7 & \text { Ibid. }
\end{array}
$$


siitä kunkin näytelmän aikakauteen sopivat asut. Esimerkiksi vanhan ajan kauniit röyhelöpuserot, naisten pitkät hameet ja miesten kaulukset olivat arvossaan. Maskeeraus oli ilmeisesti yhtä olennaista. Isoisä kertoo: ”Kemikalioliikkeistä hankittiin pohjavärit ja näyttämövärit, niit myytiin oikein semmosel'näyttämöväri'-nimel. En mää sunkka huomannu, että siitä mittä haitta olis ollu ihol. Parkkiintunu nahka, kyl se sen kesti." Kulmakarvoja ja partoja kiinnitettiin liimalla, joka vähän karvasteli. ”Maskeeraustaito oli sellainen, että ei se aina niin onnistunut kun maalin kanssa sudittiin, kyllä oli monta kertaa aika siivoominen. [... ] Mutta puhdistettu vaseliini oli hyvä, kun sitä veti siihen ja sellstoffilla veti, niin kyllä sillä ne värit saatiin pois

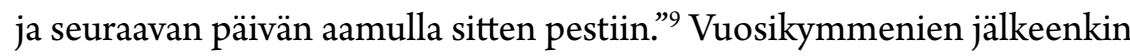
isoisäni vaikuttaa melkoiselta meikkausekspertiltä, mutta valokuvan ja sen huulipunan tarkempi merkitysyhteys ei vain tunnu selviävän.

\section{Eevan ja Aatamin puvussa}

Mistä näytelmästä isoisäni kuvassa voisi olla kyse, jos ristiinpukeutuminen kuului näytelmän juoneen? Kevyistä suomalaisista huvinäytelmistä kyseeseen voisi tulla ainakin Agapetuksen vuonna 1928 julkaisema Aatamin puvussa ja vähän Eevankin -romaani, joka myöhemmin sovitettiin näytelmäksi. Siitä tuli kaikkien suomalaisten puskafarssien äiti, kuten elokuvatutkijaystäväni luonnehtii. Tarinassa proviisori Himanen ja hänen luutnanttikaverinsa haaksirikkoutuvat alastomina saareen. Sittemmin Himanen tutustuu naisena esiintyen nimismiehen Alli-tyttäreen. Romaanin ensimmäinen elokuvaversio oli vuoden 1931 äänitehostettu mykkäelokuva, toinen vuoden 1940 filmatisointi, jossa Tauno Palo esittää Himasta, juo huivi päässä Allin tarjoilemaa maitoa ja keimailee elokuvajulisteessa mekossaan.
Isovanhemmillani oli Agapetuksen romaani hyllyssään, ja luinkin sen joskus lapsena heidän luonaan kyläillessäni. Nyt luen Turun pääkirjaston varastosta tilaamaani kappaletta ja ihmettelen, miten heppoisin aineksin Himanen muuntautuu kertomuksessa naiseksi. Hän huutelee alastomana puusta, johon koira on hänet ahdistanut, esittäytyy vastarannan huvilan neidiksi, laskeutuu sitten maan pinnalle nimismiehen tyttären hänelle kiikuttamassa hameessa ja jumpperissa - ja päätyy nukkumaan tämän kanssa samassa huoneessa, muka pelkkä hämärä valepukunaan.

Vuoden 1931 versiossa Joel Rinteen Himanen esiintyy Esterinä hameessa ja hihattomassa yläosassa, mutta muuten sangen maskuliinisena lyhyessä tukassaan. Vuoden 1940 Himasena Tauno Palo pitää sentään vuoteessakin jonkinlaista huiviturbaania naisellisuutta merkkaamassa. Toini Aaltonen kirjoitti Suomen Sosialidemokraatissa ilmestyneessä arvostelussaan Palon esiintymisestä tuoreeltaan: "Hän on niin verraton, että pahantuulisinkin on pakoitettu nauramaan. Kun hän kulkee kukikas naisenkolttu yllän, keikauttaa päätään ja yrittää muutenkin kanamaisella esiintymisellään antaa uskottavan kuvan naisesta, niin se on lystiä. Erikoisesti jäi mieleeni, kun kamera kuvasi hänet takaapäin hänen ottaessaan ensimmäisiä 'naisellisia' askeleitaan. Sellaista hyväntuulista ja vapaata esitystä toivoisi näkevänsä enemmän meikäläisissä komedioissa."10

Ollaan siis tukevasti sen perinteen jatkumolla, jossa naiseksi pukeutuva mies on tikahduttavan hauska luopuessaan miehisestä normaaliudesta tehdäkseen pilaa naisellisuudella, tuolla kanamaisen keikistelyn naurettavalla performanssilla. Ollaan matkalla kohti Pekkaa ja Pätkää puistotäteinä. Suomalaisissa 1930-1950-luvun elokuvissa ristiinpukeutumista olikin

10 Aaltonen, Toini. Suomen Sosialidemokraatti 20.9.1940. 
lähinnä komedioissa, erityisesti armeijaan sijoittuvissa. ${ }^{11}$ Voiko tällaisella ristiinpukeutumisella ajatella olevan sukupuolen ja seksuaalisuuden kannalta mitään muuta kuin binäärisyyttä ja heteronormatiivisuutta korostava rooli?

Judith Butler (1990, 187-188) on kirjoittanut dragin paljastavan sen, miten sukupuoli perustuu imitaatioon, ja parodioivan ajatusta luonnollisesta tai alkuperäisestä sukupuolesta. Kaikissa tapauksissa ristiinpukeutuminen ei silti kyseenalaista normatiivista sukupuolijärjestelmää ja heteroseksuaalisuutta. Butlerin $(1993,126)$ mukaan sellaisissa elokuvissa, kuin Tootsie tai Some like it hot, ristiinpukeutuminen tarjoaa ritualistisen keinon linnoittaa heteroseksuaalisuuden rajoja, joita pitää jatkuvasti varjella queerin tunkeutumisyrityksiltä. Aatamin puvussa ristiinpukeutuminen palvelee sitä paitsi juonellista tarkoitusta, jossa mies pääsee naiseksi tekeytyneenä tirkistelemään alastoman Allin voimisteluesitystä, rakastuu tähän ja lopuksi päätyy tämän kanssa suhteeseen oikean henkilöllisyytensä paljastuttua. Mies naisen vaatteissa esitetään naurettavana ja groteskina: "se oli hirviö ihmisen hahmossa. Tai ihminen hirviön hahmossa."(Agapetus 1953, 76) Harri Kalhan (2019a, 215) mukaan suomalaisissa 1930-1950-luvun elokuvissa ristiinpukeutuminen ei olekaan erityisen uhkaavaa yhteiskunnallisen järjestyksen kannalta, vaan ennemminkin juuri tällaista koomista homososiaalista hupailua.

Terrell Carver (2009) on esittänyt että esimerkiksi Some like it hot -elokuvaa voi lukea kokonaisuudessaan dystooppisena kertomuksena hetero-

11 Esimerkkeinä: Rykmentin murheenkryyni (1938), Perheen musta lammas (1941), Rakas lurjus (1955), Tyttö lähtee kasarmiin (1956), Vatsa sisään, rinta ulos (1959). Poikkeuksena 1600-luvulle sijoittuva seikkailuelokuva Sysmäläinen (1938). Tiedoista kiitokset Outi Hupaniitulle. Myöhäisemmästä ristiinpukeutumisesta suomalaisissa elokuvissa ks. esim. Kangasniemi, Hanna. 1991. "Naiseuden merkit ja mieheyden maskit: Ristiinpukeutuminen Uuno Turhapuro -elokuvissa." Teoksessa UT-tutkimusretkiäUunolandiaan, Jukka Sihvonen (toim.), 71-88. Helsinki: Kirjastopalvelu. normatiivisesta romanssista, jolloin myös ristiinpukeutuminen asettuu parodioimaan sitä. Halutessaan Agapetuksenkin tekstiä voi lukea tästä näkökulmasta. Varsinkaan Himasta ei kuvata minään mahtikarjuna. Allin ihmetellessä teoksen lopussa, ettei hän äänestäkään ollut tunnistanut Himasta mieheksi, tämä selittää: "Luoja nähköön: kurkkuni on nyt painuksissa, mutta luonnostaan minulla on korkea puheääni, ja minä silloin yöllä vielä peloissani piipitin niin kuin satakieli” (Agapetus 1953, 174). Elokuvien ristiinpukeutuminen on muutenkin monitulkintaista. Laura Horak (2016) on osoittanut, että ristiinpukeutuvat naiset olivat varhaisissa amerikkalaisissa elokuvissa yleinen ja hyväksytty ilmiö, jolla oli pitkä edeltävä historia sekä näyttämötaiteessa että kansankulttuurissa. Vasta 1920-luvulta eteenpäin osa ristiinpukeutumisista alkoi kietoutua yhteen naisten välisen seksuaalisuuden kuvaamisen kanssa.

Epäselväksi jää, oliko valokuvan tapauksessa kyse Agapetuksesta vai jostain aivan muusta näytelmästä. Mitä enemmän katson kuvaa, sitä epävarmempi olen kaikesta. Onko isoisän tarkoitus edes esittää naista? Hänen vaatteensa eivät näytä kovin naisellisilta. Onko hän pukeutunut mieheksi, jolla on silmämeikkiä, huulipunaa ja peruukki? Tällöin hän asettuisikin aivan erilaiseen valoon myös Kalhan (2019a) analyysissa, jossa elokuvien feminiiniset ja tällätyt "mieshempukat" ovat sukupuolisesti uhkaavampia kuin varsinaiset ristiinpukeutujat. Onko kuvan keskellä pienissä viiksissä poseeraava henkilö myös ristiinpukeutunut? Loppujen lopuksi koko pohdinta tuntuu palaavan ja tiivistyvän siihen tosiseikkaan, että isoisäni on laittanut huulipunaa ja kuvasta päätellen myös jollain tapaa nauttinut siitä.

Niin, kuvasta päätellen. Isoisä esiintyi meikeissään kaksinkertaisesti: iltamanäyttämön lisäksi hän asettautui valokuvallisen näkemisen ja näyttämisen kohteeksi, mitä ilman tieto hänen tälläytymisestään ei koskaan olisi saavuttanutkaan minua 80 vuoden takaa. 1900-luvun puolella syntyneillä oli ensimmäisinä ikäluokkina laajat mahdollisuudet hankkia valokuvia 
itsestään (Männistö-Funk 2010) ja myös valokuvista tuli ristiinpukeutumisen näyttämöitä.

Kuten Harri Kalha $(2019 b, 16)$ toteaa, valtaosa kaikista kuvista oli hyvin sovinnaisia. Postikorttien ja ateljeekuvien runsaan määrän takia joukosta löytyy kuitenkin myös lukuisia esimerkkejä sovinnaisuuden ja sukupuolen rajojen koettelusta. Juuri kun olen tuijotellut isoisääni meikeissä, ruotsalainen kollegani sattuu postaamaan sosiaaliseen mediaan kuvan isoäidistään ja tämän ystävättäristä miesten puvuissa 1920-luvulla. "Queering it", hän kommentoi. Minä vastaan isoisäni kuvalla. He olisivat sopineet yhteen, tuumii kollega. Ainakin he näyttävät sopineen joihinkin samantapaisiin esittäytymisen muotoihin. Jo ateljeekuvaus tarjosi yksilöllisiä tapoja tarkastella omaa sukupuolen ilmaisua, joskus myös kyseenalaistaa sen normeja pienillä valinoilla. Kuvattava osallistui aktiivisesti poseerauksella tietynlaiseen oman ruumiinsa esittämiseen. Asentoihin ja ilmeisiin saatiin vaikutteita esimerkiksi elokuvista. (Ijäs 2008.) Kun valokuvaus levisi ateljeiden ulkopuolelle, yhdeksi kuvien lajityypiksi muodostuivat lavastetut hupailut, näiden joukossa ristiinpukeutumiskuvaelmat, esimerkiksi häät (Toedtemeier 2005). Yleisön ja kameran linssin edessä leikittiin siis sukupuolella, mutta oliko kyseessä sama ilmiö paikasta riippumatta? Palaan pohtimaan paikan vaikutusta mahdollisiin identiteetteihin ja niiden performointeihin. Mikä merkitys on sillä, että huulipunaa laitettiin juuri tietyn pienen työväentalon näyttämön takana kahden pienen kylän rajalla, Naarjoen-Turajärven puskissa?

\section{Naarjoen puskista Berliiniin ja takaisin}

Horak (2016) varoittaa, että houkutus lukea monitulkintaista historiallista ristiinpukeutumista tämän päivän sukupuolisten tai seksuaalisten identiteettien ja merkitysten näkökulmista voi hämärtää sitä, millaisia merkityksiä sillä oli omana aikanaan. Historioitsijan ylin ohjesääntö on pyrkiä tekemään oikeutta menneisyyden ihmisille (Kalela 2000), joten tämä ei ole mikään pikkuseikka. Liimaanko Horakin kritisoimalla tavalla jonkin oman pohdintani isoisäni päälle? Sillä isoisän huulipunahan kiinnostaa minua nimenomaan queerin näkökulmasta. En voi tietää isoisäni tarkoitusperiä, sitä tekikö hän tarkoituksellisesti vinouttavan teon. Mutta oliko hänen huulipunansa tarkoitusperästä riippumatta queer? Tämä onkin vaikeampi kysymys. Varovasti väitän, että sen voidaan ajatella olleen tai olevan, että se itsessään haastoi tai avasi jotakin. Mietin myös, olenko itse tarpeeksi queer kirjoittamaan siitä, onko jokin queer? En, kyllä, ehkä. Olisinko enemmän tai tarpeeksi queer, jos sukuni tulisi jostain muualta kuin Naarjoen puskista? Ja lopulta: Millaiset identiteetit ja millaiset performoinnit ovat mahdollisia missäkin ajassa ja paikassa? Riikka Taavetti $(2018,38)$ tähdentää väitöskirjassaan, että juuri tietämisen mahdottomuus ja tietämättömyydestä kumpuava voima ovat queerin ja historian risteymän sydän. Voimme nähdä välähdyksiä ja lukea fragmentteja, mutta emme voi saavuttaa kaikenkattavaa ymmärrystä. Kun kurkistan isoisäni kuvitteelliseen meikkipussiin, en näe siellä niinkään pappaa kuin itseni, miettimässä erojen merkitsevyyttä, historian eri puolia, itseäni historian miettijänä.

Kun ajattelen isoisäni huulipunaa, ajattelen sitä performatiivisena sukupuolen rajojen rikkomisena tai niistä poikkeamisena, vaikka kuinkakin pienenä ja ohimenevänä. Näen sen mahdollisesti queerina Eve Kosofsky Sedgwickin tarkoittamalla tavalla. Hänen mukaansa queer voi käsittää suuren moninaisuuden kaikenlaisia poikkeavuuden, vastustuksen ja normien murtamisen muotoja, joilla ei välttämättä ole mitään tekemistä niitä toteuttavan ihmisen seksuaalisen suuntautumisen kanssa. Sedwigckin (1993, xii, 48) mukaan tämä laaja queerin käsite ei silti aseta kyseenalaiseksi samansukupuolista halua queerin kovana, luovuttamattomana ytimenä. Laura Doanin (2010,370-373) mukaan juuri Sedgwick on queer-teorian suurista nimistä historiatietoisin, joten hänen näkemyksensä tuntuu olennaiselta 
yrityksessä ymmärtää 1920-luvun kravatteja ja 1930-luvun huulipunia. Sedgwickiä mukaillen queerissä on pohjimmiltaan kysymys sukupuolen tai seksuaalisuuden ei-normatiivisista muodoista, mutta kokonaisuutena se koostuu hyvin monenlaisista, hetkellisistä, performatiivisista, sukupuolta tai seksuaalisuutta outouttavista teoista.

Gai Pied -lehdelle vuonna 1981 antamassaan haastattelussa Michel Foucault toteaa jotakuinkin näin: Olennaisinta ei niinkään ole tunnistaa itsessään omaa seksuaalisuuttaan kuin käyttää seksuaalisuuttaan suhteiden luomisen välineenä. Vähän myöhemmin hän sanoo vielä: Meidän pitää tehdä töitä tullaksemme homoseksuaaleiksi eikä vain keskittyä tuntemaan olevamme sellaisia. (Foucault 1996, 310.) Pohdin tätä toteamusta rinnan sen kanssa, mitä Horowitz kirjoittaa sukupuolen performanssista ja performatiivisuudesta: Ettei niiden välillä lopulta ole nähtävissä varsinaista eroa, jos subjektin ei ajatella edeltävän tekojaan, vaan uusmaterialisesti syntyvän niissä, intra-aktiossa kaiken ympäröivän ja mahdollistavan kanssa. Tämä relationaalisuus mahdollistaa Horowitzin mukaan queerin sekä ruumiillisena että diskursiivisena ilmiönä. (Horowitz 2013, 321.) Kaikki mitä olemme tai voimme ajatella olevamme, on seurausta materiaalisajattelevasta olomuodostamme, joka puristuu tietynlaiseksi suhteissa muihin, yhtälailla muotoutumisen tilassa oleviin. Siksi ei ole samantekevää millaisen materiaalisen kokonaisuuden osaksi joku voi asettua. Ei ole yhdentekevää ristiinpukeutua ja olla tilanteissa, joissa ristiinpukeutuminen on mahdollista.

Palaan mielessäni Berliiniin, silloisten ja nykyisten pervojen mekkaan. On sekä valaisevaa että hämäävää verrata Berliinin klubien "stage-dragia" Naarjoen-Turajärven työväentalon näyttämömeikkeihin. Suomalaiset puskafarssit olivat täysin erilainen kulttuurinen ja materiaalinen ympäristö kuin Berliinin 1920-luvun lesboseurapiirit. Mutta silti moderni tapahtui molemmissa, ja myös sukupuolta neuvoteltiin. Molemmissa aukesi jon- kinlainen mahdollisuus sukupuolen performanssin parodiaan, erilaisena esiintymiseen. Taavetti (2018) teroittaa tarvetta tarkastella queerin ajallista ja paikallista rakentumista, niin käsitteenä kuin historiallisesti tutkittavina ilmenemismuotoina. Queeria voidaan käyttää historiantutkimuksen välineenä käsiteltäessä jotain vaikeasti hahmotettavaa, vain välähdyksenomaisesti esiin nousevaa. Queer on nykyisen kulttuurin kategoria, mutta auttaa ymmärtämään ja nostamaan esiin sekä menneitä että nykyisiä mahdollisuuksia normien ulkopuoliseen seksuaalisuuteen tai sukupuoleen.

Naarjoen puskat ja Berliinin klubit eivät olleet vain erilaisia ympäristöjä erilaisine mahdollisuuksineen sukupuolen ja seksuaalisuuden normien rajojen rikkomiselle. Näissä kahdessa paikassa myös sukupuoli ja seksuaalisuus olivat erilaisia.Jan Löfströmin (1999) mukaan sukupuoliero suomalaisessa agraarikulttuurissa 1800-luvun lopulla ja 1900-luvun alussa erosi kansainvälisen keskiluokan sukupuolikäsityksistä. Toisin kuin keskiluokkaisessa sukupuolijärjestelmässä, sukupuolten vastakkaisuuden painottaminen ei ollut erityisen tärkeää, eikä esimerkiksi naismaisia miehiä tai miesmäisiä naisia koettu uhkina. Toisaalta taas luokkaero oli maaseudun käytäntöjä ja asenteita vahvasti järjestävä tekijä. Kansanihmisten kuului toimia toisin kuin "herrojen", myös sukupuolisuuden alueella. Seksuaalinen säädyttömyys yhdistettiin varsinkin nuorilla naisilla liian herraskaisiin, koreileviin tai uusmuotisiin vaatteisiin ja esimerkiksi meikkaamiseen. (Mikkola 2009.) Väitöskirjassani (Männistö-Funk 2014) olen esittänyt, että onkin tarpeen tarkastella erikseen maaseudun modernisaatiota, eräänlaista itsetehtyä modernia, joka liittyy urbaaniin, kansainväliseen moderniin mutta myös eroaa siitä ja muokkaa sen ilmiöitä omiin tarpeisiinsa, käytäntöihinsä ja merkityksiinsä soveltuviksi.

Itse tekemisellä oli agraariyhteisössä erityinen arvonsa. Haastattelunauhalla kuulen isoisäni äänessä yhden kerran hieman ärtymystä. Tämä tapahtuu kun haastattelija kysyy, mistä uusia ideoita kulkeutui Naarjoelle, työväen-
SQS

$1-2 / 2019$

65

Pervopeili Artikkelit

Artike lit 
yhdistyksen kulttuuritoimintaa varten. Isoisä vastaa kipakasti: ”Jaa, en minä tiä. Ei niitä kulkeutunu kyl mistää, kyl se oli ihan semmost oma-alotteista." ${ }^{12}$

Käytännössä myös Naarjoen-Turajärven työväentalo tietysti oli monenlaatuisten ja laajojen kulttuuristen vaikutteiden ja ideoiden kohtauspaikka, mutta tämän suuremman kuvion näkeminen ei vähennä itsetekemisen merkittävyyttä sosiaalisena ja kulttuurisena työnä. Huvinäytelmien kaltaisten kulttuurituotteiden omaehtoinen uudelleentuottaminen ja -tulkitseminen voidaan nähdä monimutkaisena neuvotteluna muun muassa suhteesta modernin urbaanin kulttuurin sukupuoli- ja seksuaalisuuskäsityksiin. Näyttelijöiden kuvassa huomion kiinnittää se, että he ovat naamioituneet toiseen luokkaan, herroiksi ylioppilaslakkeineen ja kävelykeppeineen. Miksi ikinä isoisäni onkaan naamioitunut, ei hän ainakaan esitä oman elinympäristönsä tavallista naista tai miestä, vaan jotakin hieman yliampuvaa kuvitelmaa, jonkinlaista sukupuolen äären tai ytimen parodiaa tai liioittelua. Meikkauksen yleinen kulttuurinen paheksuttavuus hänen elinympäristössään tekee huulipunasta erityisen vahvan merkin, ristiinpukeutumiseen liittyvän, tahallisen yliampuvan elementin. Arto Jokinen $(2001,208)$ on väittänyt, että ympäristöstä riippumatta suurin osa ristiinpukeutujista on miehiä, jotka pukeutuvat äärimmäisen feminiinisiksi naisiksi. Lisäkierteen tällaiseen äärimmäisyyteen tuo tässä tapauksessa maalaisympäristö, jossa sukupuolen performointi muutoin oli vähäeleistä ja kurinalaista. Siinä ympäristössä mieheksi tunnistetun saattoi olla helpompi laittaa huulipunaa kuin naisen. Isoäidilläni en muista koskaan nähneeni mitään meikkiä.

12 Oiva Männistön haastattelu, Tampereen yliopiston kansanperinteen arkisto, äänitekokoelmat, Y 08381/1979-06-10.

\section{Kansan queer}

Hyvin pian tämän huulipunaepisodin jälkeen alkoi sota, johon isoisäni osallistui alusta loppuun, kotimaansa mukana myös Saksan kanssasotijana, taisteluissa, joista suomalaisessa kulttuurissa tulisi nationalistisen maskuliinisuuden kulmakivi. Claire Waldoff tahollaan joutui ennen sotaa ongelmiin epäillyistä kommunistisista yhteyksistä ja oli esiintymiskiellossakin, mutta toisaalta myös lauloi vuonna 1942 saksalaisille sotilaille miehitetyssä Pariisissa. Taiteilija Martin Dammann (2018) on kerännyt yksityisistä kokoelmista satoja kuvia naisiksi pukeutuneista sotilaista toisessa maailmansodassa ja todennut ristiinpukeutumisen olleen erityisen yleistä Saksan armeijassa, siis järjestelmässä, joka samaan aikaan teki kaikkensa homoseksuaalien vainoamiseksi ja murhaamiseksi. Dammann yhdistää ilmiön saksalaisten vahvaan karnevalistiseen perinteeseen, mutta tästä selityksestä huolimatta törmäämme taas täydellisen tietämisen mahdottomuuteen ja tuijotamme hiukan neuvottomina paljettimekkoihin tälläytyneitä sotilaita. Mistä kimmoke ristiinpukeutumiseen eri tilanteissa tuli? Mitä ristiinpukeutujat mahtoivat ajatella? Miltä heistä tuntui?

Suomen armeijassakin ristiinpukeuduttiin sodan aikana, usein viihdytystarkoituksissa. Jatkosodassa rintamadrag muodostui viihteenlajiksi, jolla oli omat tähtiesiintyjänsä. Sari Näre siteeraa kommentteja aiheesta Olavi Paavolaisen Synkästä $y k s i n p u h e l u s t a$. Paavolainen kuvailee balettitanssijoiksi pukeutuneita miesryhmiä sekä näitä "naiivin yksinkertaisina" valokuvaavia rintamatovereita ja antaa maailmanmiehen varmuudella oman tuomionsa, jota ei usko innokkaiden valokuvaajien ymmärtävän: "selvää transvestismiä". (Näre 2008, 374; Näre 2016, 167.) Paavolainen tuntuu siis ajattelevan, että epäilyttävä transvestismi sekä on että ei ole läsnä tällaisissa ristiinpukeutumiskäytännöissä ja -esityksissä, riippuen katsojan - ja jopa esiintyjän - tietämyksen tai ymmärryksen tasosta. Palataan siis kysymykseen tarkoitusperästä, jonka yksillä oletetaan olevan vinoutunut,
SQS

$1-2 / 2019$

\section{6}

Pervopeili Artikkelit 
paheellinen ja latautunut - meidän näkökulmastamme queer - ja toisilla taas viaton, lapsekas ja syvempää merkitystä vailla.

Samantapaisesti Kalha (2019a, 215) liittää suomalaisten elokuvien ristiinpukeutumisen valtavirran analyysissaan "harmittomaan kansankulttuuriin", joka ei uhkaa sukupuolijärjestelmää, toisin kuin joidenkin elokuvien taiteellisen dekadentit mieshahmot. Mutta miksi sekä Paavolaisen että Kalhan analyysissa nähdään nimenomaan maalaisten ja koulutustasoltaan alempien, niin sanottujen kansanihmisten, suhtautuminen ristiinpukeutumiseen yksinkertaisena, vaarattomana ja traditionaalisena? Tekeekö tämä heille oikeutta? Mikä lopulta on harmitonta kulttuuria ja kuka sen määrittää?

1900-luvun alkupuoliskon moderniin kulttuuriin kuului vastakohtaisuuksien rakentaminen kaupungin ja maaseudun, korkeakulttuurin ja kansanperinteen sekä ulkomaisen ja kotimaisen välille (Murphy 2010, 185-192). Kun katsotaan pintaa syvemmälle, tämän modernin vastakohta-asettelun taa, ei kuitenkaan löydetä muuttumattoman harmitonta kansankulttuuria vaan jatkuvaa erilaisten vaikutteiden sulauttamista ja neuvottelemista, myös sukupuolen ja seksuaalisuuden osalta. Naarjoen puskat eivät siis ole Berliinin näyttämöiden vastakohta, vaikka selvästi eroavatkin niistä. Näiden paikkojen ristiinpukeutumiset liittyvät toisistaan eroaviin sosiaalisiin rakenteisiin ja esiintymistraditioihin, mutta ovat kuitenkin myös samalla kulttuurijatkumolla, jossa sukupuolta ja seksuaalisuutta voidaan käsitellä, venyttää tai vinouttaa dragin keinoin. Isoisän huulipuna näyttäytyy merkityksellisenä, niin yksityisenä ruumiillisena kokemuksena kuin myös osana koko aikalaismaailmaansa kietovaa kulttuurista muutosta ja neuvottelua.

\section{Kirjallisuusluettelo}

Agapetus. 1953. Aatamin puvussa ja vähän Eevankin: Kevyt romaani. Kahdeksas painos, ensimmäinen painos ilmestynyt 1928. Helsinki: Kustannusosakeyhtiö Otava.

Butler, Judith. 1990. Gender Trouble: Feminism and the Subversion of Identity. New York: Routledge.

Butler, Judith. 1993. Bodies that Matter: On the Discursive Limits of "Sex". New York: Routledge.

Carver, Terrell. 2009. "Sex, Gender and Heteronormativity: Seeing 'Some Like It Hot' as a Heterosexual Dystopia.” Contemporary Political Theory 8(2), 125-151.

Dammann, Martin. 2018. Soldier Studies: Cross-Dressing in der Wehrmacht. Berlin: Hatje Cantz.

Doan, Laura. 2010. "Forgetting Sedgwick." PMLA 125(2), 370-373.

Foucault, Michel. 1996. "Friendship as a Way of Life." Teoksessa Foucault Live: Interviews, 1961-1984, ranskasta kääntänyt John Johnston. New York: Semiotext(e), 310 .

Haapala, Pertti. 2003. "Nuoriso numeroina." Teoksessa Nuoruuden vuosisata: Suomalaisen nuorison historiaa, toimittaneet Sinikka Aapola ja Mervi Kaarninen, 66-85. Helsinki: SKS.

Horak, Laura. 2016. Girls will Be Boys: Cross-Dressed Women, Lesbians and American Cinema, 1908-1934. New Brunswick: Rutgers University Press.

Horowitz, Katie R. 2013. "The Trouble with 'Queerness': Drag and the Making of Two Cultures.” Signs 38(2), 303-326.

Ijäs, Minna. 2008. "Kuviteltu ja koettu ruumis valokuvamuotokuvassa: Uudenlaisia esittäytymisen tapoja käyntikorttikuvissa 1910-1920 -luvuilla." Naistutkimus 4/2008, 16-30.

Jokinen, Arto. 2001. "Näin tehdään nainen: Miesten ristiinpukeutuminen." Teoksessa Nainen/naiseus/naisellisuus, toimittaneet Minna Nikunen, Tuula Gordon, Sanna Kivimäki ja Riitta Pirinen, 191-212. Tampere: Tampere University Press.

Kalela, Jorma. 2000. Historiantutkimus ja historia. Helsinki: Gaudeamus.

Kalha, Harri. 2019a. "Hinttareita, onko heitä? Sukupuolipolitiikkaa SF-tyyliin." Teoksessa Unelmatehdas Liisankadulla: Suomen Filmiteollisuus Oy:n tarina, toimittaneet Kimmo Laine, Minna Santakari, Juha Seitajärvi ja Outi Hupaniittu, 212-227. Helsinki: SKS.
SQS

$1-2 / 2019$

Pervopeili

Artikkelit

Artikelit

\footnotetext{
.
} 
Kalha, Harri. 2019b. Sukupuolen sotkijat: Queer-kuvastoa sadan vuoden takaa. Helsinki: Parvs.

Koreen, Maegie. 2014. Claire Waldoff: Die Königin des Humors. Gelsenkirchen: Chanson-Café.

Löfström, Jan. 1999. "Se nyt vaan on semmonen”: Sukupuoliero agraarikulttuurissa. Helsinki: Suomalaisen Kirjallisuuden Seura.

Mikkola, Kati. 2009. Tulevaisuutta vastaan: Uutuuksien vastustus, kansantiedon keruuja kansakunnan rakentaminen. Helsinki: Suomalaisen Kirjallisuuden Seura, 249.

Mungen, Anno. 2006. “'Anders als die Anderen', or Queering the song: Construction and Representation of Homosexuality in German Cabare Song Recordings before 1933." Teoksessa Queering popular pitch, toimittanut Sheila Whiteley,67-79. New York: Routledge.

Murphy, Kate. 2010. Fears and Fantasies: Modernity, Gender, and the RuralUrban Divide. New York: Peter Lang.

Männistö, Tapio. 2014. Torpan tarinoita. Pori: Omakustanne.

Männistö, Tapio. 2017. Kirjeitä ja karvakorvia. Pori: Omakustanne.

Männistö-Funk, Tiina. 2010. 'Monien käytäntöjen 'kovat kuvat': Käyntikorttikuvat suomalaisissa maaseutukodeissa 1900-luvun alussa." Teoksessa Esine ja aika: Materiaalisen kulttuurin historiaa, toimittaneet Riitta Laitinen ja Maija Mäkikalli, 249-278. Helsinki: SKS.

Männistö-Funk, Tiina. 2012. "The prime, decline and recalling of rural cycling: Bicycle practices in the 1920s' and 1930s' Finland remembered in 19711972." Transfers - Interdisciplinary journal of mobility studies 2(2), 4969.

Männistö-Funk, Tiina. 2014. Itse tehty moderni: Gramofoni, polkupyörä ja valokuvaus suomalaisten elämässä 1880-luvulta 1940-luvulle. Turku: Turun yliopisto.

Männistö-Funk, Tiina. 2019. "Introduction: The historical production of the invisible and visible bicycles." Teoksessa Invisible Bicycle: Parallel histories and different timelines, toimittaneet Tiina Männistö-Funk ja Timo Myllyntaus, 1-20. Leiden: Brill.

Nurmela, Johanna. 2005. "Kesäiset lavatanssit Jurvassa: 1950-luvun Suomi ja suuri tanssi-innostus.” Teoksessa Saanko luvan? Iskelmä-Suomen ilmiöitä 1900-luvulla, toimittanut Leena Rossi, 60-77. Turku: K\&h, Turun yliopisto, Kulttuurihistoria.
Näre, Sari. 2008. "'Kuin viimeistä päivää' - sota-ajan sukupuolikulttuuri ja seksuaalinen väkivalta." Teoksessa Ruma sota: Talvi- ja jatkosodan vaiettu historia, toimittaneet Sari Näre \& Jenni Kirves,335-380. Helsinki: Johnny Kniga.

Näre, Sari. 2016. Sota ja seksi: Rintamamiesten seksuaalikerrontaa talvi- ja jatkosodan ajalta. Helsinki: Tammi.

Pesola, Sakari. 1996. "Tanssikiellosta lavatansseihin.” Teoksessa Rillumarei ja valistus: Kulttuurikahakoita 1950-luvun Suomessa, toimittanut Matti Peltonen, 105-126. Helsinki: SHS.

Raber, Ralf Jörg. 2003. “'Wir ... sind, wie wir sind!' Homosexualität auf Schallplatte 1900-1936." Invertito - Jahrbuch für die Geschichte der Homosexualitäten 5, 39-66.

Sedgwick, Eve Kosofsky. 1993. Tendencies. Durham: Duke University Press.

Suominen, Jaakko. 2018. "Mustat silmänaluset." Teksti blogissa Koneen kokemus \& tietokoneen takapuoli. 4.12.2018.

Taavetti, Riikka. 2018. Queer Politics of Memory: Undisciplined Sexualities as Glimpses and Fragments in Finnish and Estonian Pasts. Helsinki: Faculty of Social Sciences, University of Helsinki.

Toedtemeier, Terry. 2005. "Photography's love child: Origins of the snapshot." Teoksessa Snapshot Chronicles: Inventing the American Photo Album, toimittaneet Barbara Levine ja Stephanie Snyder, 183-189. New York: Princeton Architectural Press.
SQS

$1-2 / 2019$

Pervopeili Artikkelit

Artikelit 